Research Paper

\title{
Tank bromeliad water: Similar or distinct environments for research of bacterial bioactives?
}

\author{
F.L. Carmo ${ }^{1,2}$, H.F. Santos ${ }^{1}$, R.S. Peixoto ${ }^{1}$, A.S. Rosado ${ }^{1}$, F.V. Araujo ${ }^{3}$ \\ ${ }^{1}$ Departamento de Microbiologia Geral, Instituto de Microbiologia Professor Paulo de Góes, \\ Universidade Federal do Rio de Janeiro, Rio de Janeiro, RJ, Brazil. \\ ${ }^{2}$ Programa de Pós-Graduação em Biotecnologia Vegetal, Universidade Federal do Rio de Janeiro, \\ Rio de Janeiro, RJ, Brazil. \\ ${ }^{3}$ Departamento de Ciências, Faculdade de Formação de Professores, \\ Universidade do Estado do Rio de Janeiro, Rio de Janeiro, RJ, Brazil.
}

Submitted: March 4, 2013; Approved: April 1, 2013.

\begin{abstract}
The Atlantic Rainforest does not have a uniform physiognomy, its relief determines different environmental conditions that define the composition of its flora and fauna. Within this ecosystem, bromeliads that form tanks with their leaves hold water reservoirs throughout the year, maintaining complex food chains, based mainly on autotrophic and heterotrophic bacteria. Some works concluded that the water held by tank bromeliads concentrate the microbial diversity of their ecosystem. To investigate the bacterial diversity and the potential biotechnology of these ecosystems, tank bromeliads of the Neoregelia cruenta species from the Atlantic Rainforest in Brazil were used as models for this research. Bacteria isolated from these models were tested for production of bioactive compounds. DGGE of the water held by tank bromeliads was performed in different seasons, locations and sun exposure to verify whether these environmental factors affect bacterial communities. The DGGE bands profile showed no grouping of bacterial community by the environmental factors tested. Most of the isolates demonstrated promising activities in the tests performed. Collectively, these results suggest that tank bromeliads of the $N$. cruenta species provide important habitats for a diverse microbial community, suggesting that each tank forms a distinct micro-habitat. These tanks can be considered excellent sources for the search for new enzymes and/or new bioactive composites of microbial origin.
\end{abstract}

Key words: bromeliad, Atlantic Rainforest, bacteria communities, DGGE.

\section{Introduction}

Biotechnology is based on the search for and discovery of industrially exploitable biological resources. A classical approach to the stages of biotech search and discovery can be briefly summarized as follows: collection of suitable biological material, screening and selection of materials with desired attributes, final selection of the best candidate from a short list of options and development of a commercial or industrial process (Bull and Stach, 2004).

One of the main tasks of applied microbiology to biotechnology is to develop procedures for obtaining new mi- crobial metabolites within a wide diversity. There seems to be a dependence relationship between biotechnology and biodiversity, which in this context can be seen as a vast reservoir of genetic resources that serves as base for exploring biotechnology (Lopes et al., 2005).

Most of Brazil's large diversity of ecosystems has been little studied as a source of germplasm. The Atlantic Rainforest, one of the 34 hot spots in the world, has hardly been explored for bioprospection of microorganisms used in biotechnology. In those ecosystems, the water held by tank bromeliads is an excellent model as those bromeliads' leaves form a holding cup that accumulates water as well as

Send correspondence to F.L. Carmo. Departamento de Microbiologia Geral, Instituto de Microbiologia Professor Paulo de Góes, Universidade Federal do Rio de Janeiro, Rio de Janeiro, RJ, Brazil. E-mail: flavialcbio@hotmail.com. 
organic material below the plant rosette, creating microclimatic conditions that can sustain a diverse microbiota (Goffredi et al., 2011). They are largely distributed and can concentrate the microbial diversity of the surrounding ecosystem (Araújo et al., 1998; Armbruster et al., 2002).

However, due to changes in environmental factors, that microbial diversity can vary along time. Because of the wide variation of the water conditions in the tanks, caused by their exposure to sunlight, the organisms found there are adapted to rapid recolonization, which allows for shortterm studies (Lopez et al., 1993).

Studies have shown that exposure to sun or shade affects the composition and diversity of the community in the water held by the tank bromeliads, as well as its microbial diversity (Hagler et al., 1993; Lopez and Rios, 2001). Disturbances are also important ecological factors affecting microbial diversity in natural environments.

Our objective was to evaluate whether there are species with potential biotechnological application in the bacterial diversity found in $N$. cruenta tank bromeliads and how that bacterial diversity behaves under changes in environmental factors.

\section{Materials andMethods}

\section{Sampling}

50 to $100 \mathrm{~mL}$ of water was aseptically collected from the tanks of Neoregelia cruenta at 2 different sites (Costão de Itacoatiara and Costão do Córrego dos Colibris) at Parque Estadual da Serra da Tiririca (PEST) $\left(22^{\circ} 48^{\prime}-23^{\circ} 00^{\prime} \mathrm{S}\right.$; $\left.42^{\circ} 57^{\prime}-43^{\circ} 02^{\prime} \mathrm{W}\right)$, located between Niterói and Maricá, RJ, in summer, autumn, winter and spring. Six individuals were sampled at each site in each collection; three were exposed to the sun and three were located in the shadow.

\section{Sampling process}

In the laboratory, the samples were divided into two subsamples; one for heterotrophic bacteria counts and colimetric assays and the other for molecular analysis. To the latter, $50 \mathrm{~mL}$ of water was then filtered on nitrocellulose filters of 3.0 and $0.22 \mu \mathrm{m}$ pore and $47 \mathrm{~mm}$ in diameter with the aid of a vacuum pump. Filters were stored in $1.5 \mathrm{~mL}$ microtubes at $-20{ }^{\circ} \mathrm{C}$ for DNA extraction.

\section{Bacterial counts}

Heterotrophic bacteria counts by spread plate methods in nutrient agar were performed. Colonies with different morphologies were selected for further purification on nutrient agar and were stored at $-80^{\circ} \mathrm{C}$ with glycerol to be later subjected to biotechnological tests. Coliform (totals and thermotolerants) counts by multiple-tube methods were performed, just to verify anthropogenic contamination in those microhabitats (APHA, 1998).

\section{DNA extraction}

DNA extraction was performed using the DNA extraction kit for soil (FastDNA® SPIN Kit for Soil) (BIO 101,Califórnia, EUA) following the manufacturer's advice, but instead of soil, half of $0.22 \mu \mathrm{m}$ nitrocellulose filters containing filtered water sample was added.

\section{PCR/Denaturing Gradient Gel Electrophoresis (DGGE)}

PCR/DGGE experiments were performed with Bacteria universal set of primers U968f-GC1-L1401 (Heuer and Smalla, 1997). Before DGGE analysis, the presence of PCR products was confirmed by electrophoresis in a $1.2 \%$ agarose gel run at $80 \mathrm{~V}$ in Tris-Borate- EDTA buffer. The gel was stained with $0.5 \mu \mathrm{g} / \mathrm{mL}$ ethidium bromide for 15 min then it was examined under short-wavelength ultraviolet light. A 100 bp DNA ladder (Fermentas, Lithuania) served as the molecular size standard. DGGE of the amplified gene sequences was performed using a DCode System (universal mutation detection system; Bio-Rad). The gel contained $6 \%$ acrylamide with a gradient of $45 \%$ to $65 \%$ denaturant (urea and formamide). All gels were loaded with DNA markers in the first and last lanes surrounding the lanes with samples to allow gel standardization according to the manufacturer's instructions.

Electrophoresis was performed in $1 \mathrm{X}$ Tris-acetateEDTA buffer at $60^{\circ} \mathrm{C}$ at a constant voltage of $75 \mathrm{~V}$ for $16 \mathrm{~h}$. Then, the gels were stained with Sybr Gold (Invitrogen) and visualized using Storm 860 Imaging System (GE Healthcare). The results were presented as dendrograms constructed after image capture and analyzed by Pearson correlation coefficients (r). The cluster analysis was performed by the unweighted pair group method with average linkages (UPGMA) using BioNumerics software (Applied Maths, Belgium).

\section{DGGE gel analysis}

DGGE bands were identified and the intensity was measured using BioNumerics software (Applied Maths, Ghent, Belgium). The matrix containing the relative area of each band in the different regions of the samples was generated and used for the detrended correlation analysis (DCA), revealing the linear distribution of data (Adreote et al., 2009). Then the clustering of the samples was first analyzed by principal component analysis (PCA), using as input the matrices of band intensities in each of the analyzed samples. Those analyses were carried out using Canoco (Canoco 4.5, Biometris, Wageningen, The Netherlands) (Ter Braak and Smilauer, 2002).

Diversity indices were also calculated: richness $(S)$ was determined from the number of bands in each lane, and the Shannon-Wiener index $\left(H_{-}\right)$was calculated from $H_{-}=-\Sigma_{-} P i . \ln P i$, where $P i$ is the importance probability of the bands in a lane, calculated from $n i / N$, where $n i$ is the 
peak height of a band and $N$ is the sum of all peak heights in the densitometric curve. Evenness $(E)$ was calculated as $E=H \_/ H \_\max$, where $H \_\max =-\Sigma \ln S$ (Maggurran, 1988).

\section{Enzymatic tests}

Enzymatic activity was detected through the enzymatic index (EI) which is the relation between the diameter of the substrate degradation halo and the diameter of microbial colony growth. Isolates with $\mathrm{EI} \geq 2$ were considered potential enzyme producers (Lealem and Gashe, 1994). Strains were inoculated in the form of spots in modified Bennet-Agar (MBA) plus casein (milk powder) $1 \%(\mathrm{w} / \mathrm{v})$; gelatin $0.4 \%$; and starch $1 \%$ (to verify proteolytic activity in casein and gelatin and amylolytic activity respectively) and incubated for $48 \mathrm{~h}$ at room temperature. For gelatin degradation a solution of $\mathrm{HgCl}_{2}\left(\mathrm{HgCl}_{2} 15 \mathrm{~g}, 20 \mathrm{~mL} \mathrm{HCl}\right.$ supplemented with distilled water to $100 \mathrm{~mL}$ ) was added for reading and Lugol's solution (iodine solution) was used to reveal halo of amylases. The halos and the growth of the colonies were measured with a caliper (Williams et al., 1983).

The ability of bacteria to hydrolyze cellulose was tested on carboxymethylcellulose (CMC) agar. For better visualization of the halo, after two days of incubation at 28 ${ }^{\circ} \mathrm{C}$, a solution of Congo red to $0.1 \%(\mathrm{w} / \mathrm{v})$ was used to reveal the colonies on the plates (Bairagi et al., 2002).

\section{Antimicrobial activity test}

Spots of the cultures to be tested were inoculated on the surface of BHI agar (Difco) for $24 \mathrm{~h}$ at room temperature. Then, $3.0 \mathrm{~mL}$ of semi solid cultures of type strains Corynebacterium fimi (NCTC 7547), Staphylococcus aureus (ATCC 29213) and Escherichia coli (ATCC 25922), were poured onto the surface of the colonies previously inactivated with chloroform. The production of antimicrobial substances was indicated by inhibition zones around the colony after incubation at $37^{\circ} \mathrm{C}$ for $18 \mathrm{~h}$ (Giambiagi-Marval et al., 1990).

\section{Selecting bacteria producing Bioemulsifiers}

Flasks with $20 \mathrm{~mL}$ of mineral medium were incubated under agitation (150 rpm) for $24 \mathrm{~h}$ and $48 \mathrm{~h}$ at $30{ }^{\circ} \mathrm{C}$. To evaluate the emulsifying index, $5 \mathrm{~mL}$ of the supernatant was added to diesel oil 10\% (v/v), shaken in a vortex. After $24 \mathrm{~h}$, the emulsifying index was obtained (Willumsen and Karlson, 1997).

\section{Results}

\section{Coliform counts and heterotrophic bacteria counts}

The highest counts for total and thermotolerants coliforms occurred in summer, especially in $N$. cruenta located in the shade (under bushes) in Córrego dos Colibris. All individuals sampled in that site showed total coliform counts higher than those situated in Costão de Itacoatiara. In the heterotrophic bacteria counts the lowest values occurred in dry seasons and the highest ones in wet seasons for all bromeliads sampled (Figure 1).

\section{DGGE analysis}

The PCA analysis of DGGE profile showed that the bacterial communities structure presented in the water held by the tank bromeliads was quite heterogeneous, differing among bromeliad individuals regardless of whether they had been exposed to the sun or not over the year (Figure 2). The diversity indices calculated from the PCR-DGGE banding profiles showed no significant difference between the conditions tested. However, the richness score demonstrated the major difference between the samples from Colibri and Itacoatiara regions. Unlike the evenness score,

Total Coliforms

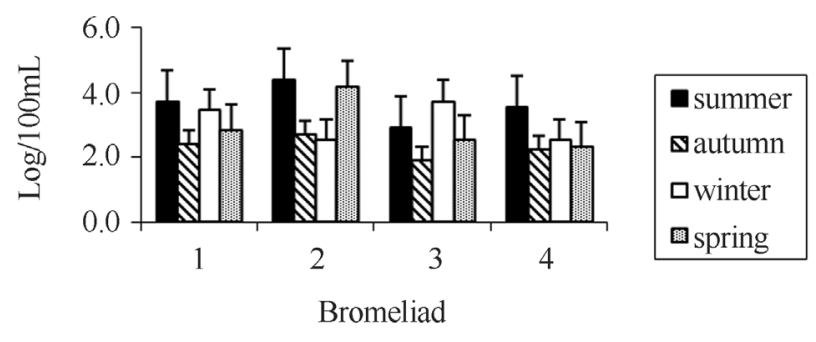

Thermotolerants Coliforms

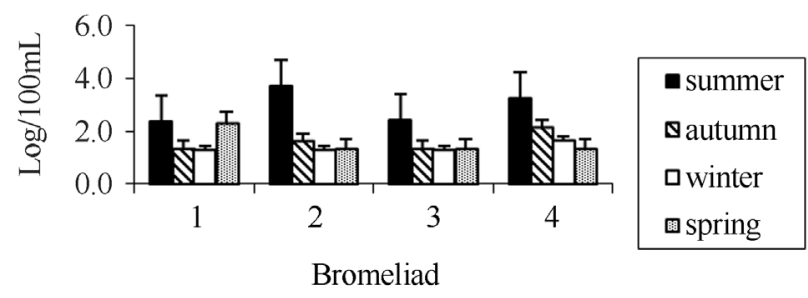

Heterotrophic Bacteria

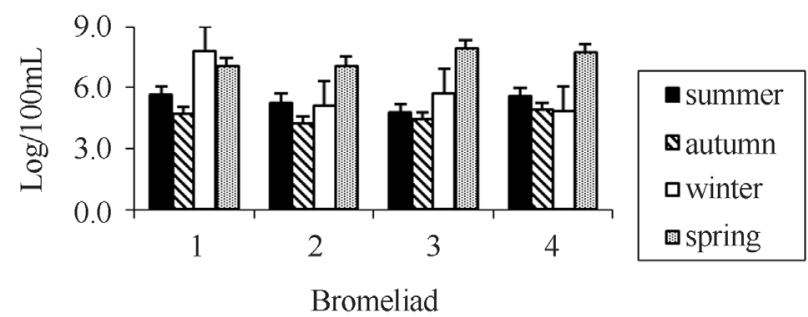

Figure 1 - Count in Log of Total Coliforms, Thermotolerant Coliforms and Heterotrophic Bacteria in N. cruenta tank bromeliads in different exposure and location. 1. N. cruenta exposed to sun located in Corrego dos Colibris; 2. N. cruenta exposed to shadow located in Corrego dos Colibris; 3. $N$. cruenta exposed to sun located in Itacoatiara; 4 . N. cruenta exposed to shadow located in Itacoatiara. 


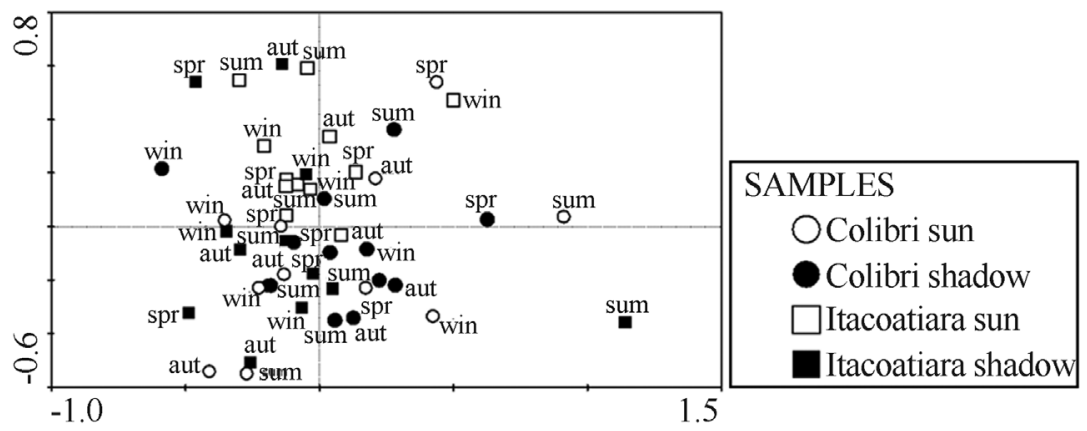

Figure 2 - Score plot of main components analysis (PCA) showing the difference among DGGE band profiles of bacterial total community of $N$. cruenta tank bromeliads in different seasons, locations and sun exposure.

the richness score showed more variation in replicates from Itacoatiara than in replicates from the Colibri region (Table 1).

\section{Enzymatic activity detection}

Among the 100 strains tested, $90 \%$ presented halo for at least one of the substrates tested, $69 \%$ hydrolyzed casein, $75 \%$ gelatin, $45 \%$ starch and $51 \%$ cellulose. Among the total of the strains that were positive in any test, 81 were considered as potential producers of enzymes for their enzymatic index was greater than or equal to 2.0 for at least one of the substrates (Table 2). Cellulolitic activity showed the best values in $46 \%$ out of the $51 \%$ strains that presented halo with enzymatic index greater than or equal to 2.0.

\section{Antimicrobial activity}

Twelve strains out of the 100 tested produced antimicrobial substances against type strain of Corynebacterium fimi. Among those, four showed strong suppression with an inhibition zone larger than $20 \mathrm{~mm}$. Against Staphylococcus aureus, five showed inhibition zone (3 with strong suppression) and against Escherichia coli, 3 (1 with strong suppression). Strains numbers 91

Table 1 - Richness, Diversity and Evenness indices calculated from the DGGE banding profiles of "total-community" bacterial of $N$. cruenta tank bromeliads in different seasons, locations and sun exposure.

\begin{tabular}{lccccc}
\hline & $\begin{array}{c}\text { Richness } \\
(\mathrm{S})\end{array}$ & $H^{a}$ & $H_{\max }^{\prime}{ }^{b}$ & $\begin{array}{c}\text { Evenness } \\
(\mathrm{E})\end{array}$ & Bands $^{\mathrm{o}}{ }^{c}$ \\
\hline Colibri & 14.5 & 2.57 & 2.70 & 0.97 & 16.5 \\
Itacoatiara & 11.6 & 2.40 & 2.52 & 0.97 & 14.1 \\
sun & 14.0 & 2.61 & 2.47 & 0.97 & 15.3 \\
shadow & 13.6 & 2.41 & 2.46 & 097 & 14.2 \\
summer & 13.2 & 2.54 & 2.41 & 0.97 & 14.2 \\
spring & 14.0 & 2.43 & 2.29 & 0.97 & 15.2 \\
autumn & 14.5 & 2.08 & 2.77 & 0.95 & 16.5 \\
winter & 14.5 & 2.44 & 2.50 & 0.97 & 15.6 \\
\hline
\end{tabular}

${ }^{a} H^{\star}$, Shannon-Wiener index.

${ }^{b} H^{c}{ }_{\max }$, maximum Shannon-Wiener index.

${ }^{c}$ Average of bands number. (with all halos over $20 \mathrm{~mm}$ ) and 3 showed inhibition zone for the three indicator strains tested.

\section{Emulsification index}

Among the strains tested, 55\% had some level of emulsion within 48 hours of growth. Of those, 35 strains had a rate of $100 \%$ of emulsion, of which $22 \%$ emulsified oil within just 24 hours of growth.

\section{Discussion}

\section{Microbial counts}

Total and thermotolerant coliforms and heterotrophic bacteria counts have been performed since previous studies noted high counts of bacteria including coliforms in the water held by bromeliads from a tropical forest in Puerto Rico and São Paulo (Rivera et al., 1988). The highest values for total and thermotolerant coliforms found in N. cruenta located in the shadow in Córrego dos Colibris can be explained by input of organic matter that these species receive and by higher probability to receive faeces of birds and other warm-blooded animals found in those bushes.

All bromeliads sampled in Córrego dos Colibris had higher counts than those found in the same species in Itacoatiara. Córrego dos Colibris is a place of limited access, covered by secondary vegetation and does not suffer from human pressures as much as Costão de Itacoatiara does. Anthropogenic pressures decrease forest area, hence decreasing the number of species that visit the bromeliads, which affects the population dynamics of plants and animals in Itacoatiara.

The lowest counts of heterotrophic bacteria occurred in the dry seasons (autumn and winter), whereas the highest counts were obtained in the rainy seasons (summer and spring) for all bromeliads sampled. That can be explained by the greater accumulation of water in the tank bromeliads in rainy seasons leading animals to visit them more often. Another study which analyzed the fauna associated with the Vriesea inflata bromeliad linking it to environmental factors also found higher abundance of macroinvertebrates in terrestrial bromeliads in the spring (Mestre et al., 2001). 


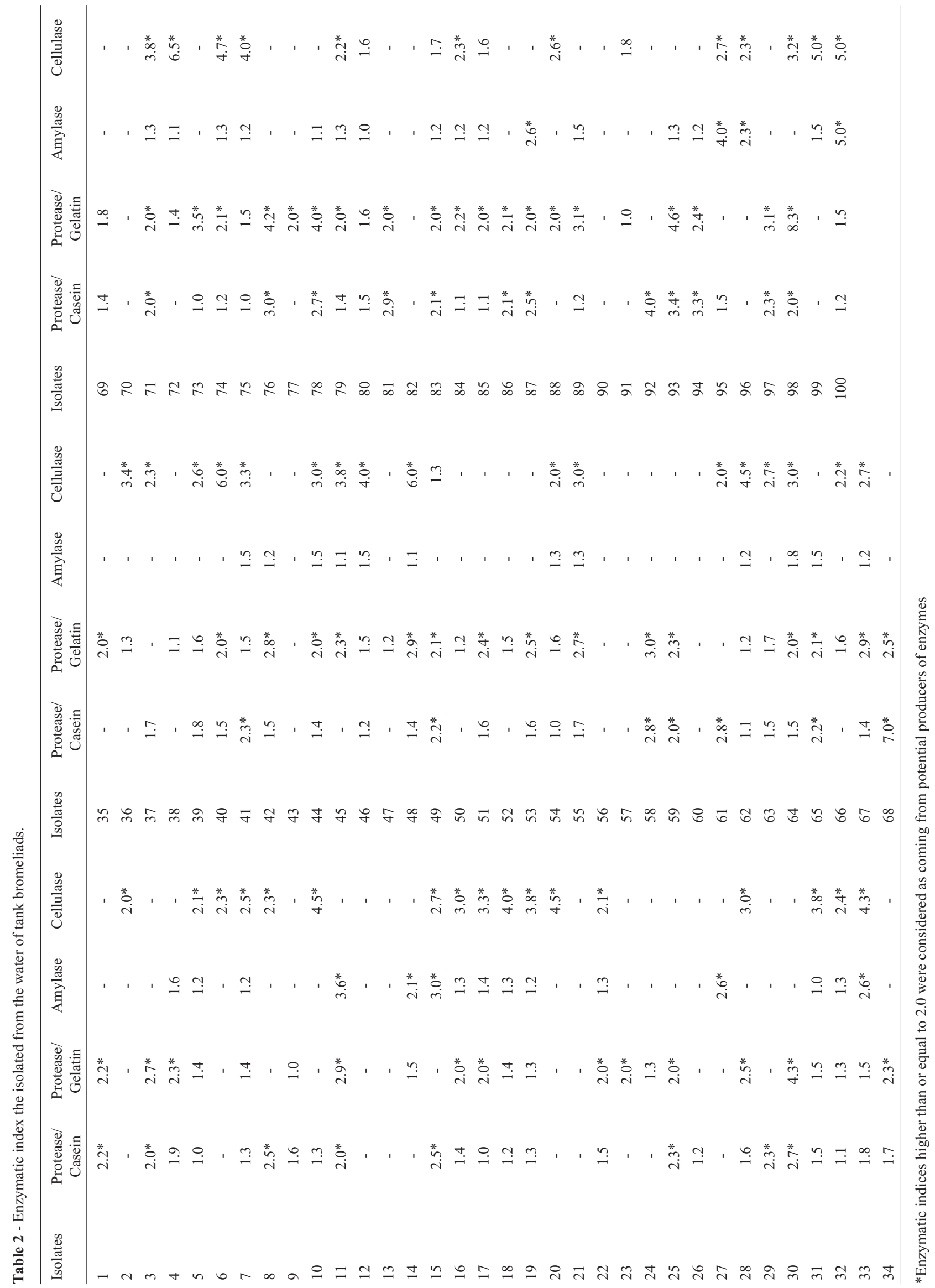




\section{Biotechnology potential}

The Atlantic Rainforest ecosystem is one of the greatest centers of biodiversity on the planet (Araujo et al., 1998; Nettesheim et al., 2010). Araujo et al. (1998), studied the water held by tank bromeliads as an example of the diversity in those tropical ecosystems and, noted that the predominant species of yeast community in tank bromeliads included many species previously found in tropical forests, which demonstrates the great potential of those microhabitats for the study of the microbial diversity existing in the ecosystem where they are. This microbial diversity represents an enormous and largely unexploited source for biotechnological applications (Weinbauer and Wenderoth, 2002). The use of enzymes in industries, antimicrobial substance production and bioremediation of oil contaminated environments are examples of such applications.

The higher number of isolates $(90 \%)$ from the water held in tank bromeliads that presented enzymatic activity for at least one of the substrates tested confirmed the potential application of the Atlantic Rainforest microbial diversity in industrial activities.

Several methods evaluate the ability of microorganisms to produce extracellular enzymes in solid medium. Among the variables that determine the choice of the most appropriate method for microbial screening is the direct relationship between the size of the halo and the degrading capacity of microorganisms (Molina et al., 2001). Leallem and Gashe (1994) suggest an enzymatic index $(=$ or $>2.0)$ to consider a microorganism as a potential producer of enzymes in solid medium. This index can be used either as a useful measure to select strains within a species or as a fast and simple parameter to select strains, as it has been successfully verified in bacteria (Mingardon et al., 2011).

Eighty-one percent of the 90 strains that showed some enzyme activity had enzymatic index greater than or equal to 2.0. Many of them showed enzymatic activity for more than one of the tested enzymes. That enzymatic versatility has been shown by groups of soil bacteria (Oliveira et al., 2006), and enzyme combinations have been widely used in industries. De Azeredo et al. (2003) cites the use of alkaline enzymes such as proteases, amylases, lipases and cellulases in detergent formulation; and Dutra et al. (2000) reports the use of exogenous enzymes in the sector of food for pigs, chickens and rabbits.

Much of the information on cellulases production has been obtained from studies that focus on the production and characterization of endoglucanases. As the best results of enzyme activity in solid medium were observed in cellulolytic tests, where $51 \%$ of the strains showed halo of degradation, and among those, $46 \%$ had enzymatic index greater than or equal to 2.0 .

Bacterial enzymes may adapt better to fermentation conditions, and may present hipercelullolytic mutants greater than those produced from fungi; purification of cellulase to degrade cellulose can be obtained more easily, and the mechanism of action of the multienzyme complex may be different and better suited to one of the most diverse uses of cellulase in industries (Lima et al., 2004).

Bacterial resistance has emerged as an important problem worldwide as many classes of antibiotics have become less effective in recent years. Therefore, the discovery of new antimicrobial substances becomes necessary (Donia and Humann, 2003). In antimicrobial production assays performed against three indicator strains, 12 strains showed inhibition zone against $C$. fimi, 5 against $S$. aureus and 3 against E.coli. Strains 3 and 91 showed strong halos of suppression for all the indicator strains tested.

Another study evaluating the production of antimicrobial substances in 86 strains isolated from Amazonia obtained only two isolates inhibiting $S$. aureus and 1 inhibiting $E$. coli, both with an average suppression (Motta et al., 2004). A high proportion of antibiotic-producing strains may be associated with their ecological function, developing a defensive action to maintain their niche (Motta et al., 2004).

Their use as food preservative due to bacteriocin production, phytopathogens and demand for antibiotics by the pharmaceutical industry are good examples of how the techniques of isolation and screening of strains from the environment are important in the selection of microorganisms for industrial application (Cherif et al., 2001). Thus, the results of this work can corroborate that bacteria present in the water held by tank bromeliads can be a viable resource for the bioprospection of a new generation of pharmacological agents.

Half of the strains tested showed a great level of emulsification. Among the 35 that presented $100 \%$ of emulsification, 22 showed it just 24 hours after incubation. Considering that the promising use of biosurfactants to remove heavy metals from soils and sediments and the effectiveness of various biosurfactants produced by bacteria, yeasts and plants have already been proved (Hong et al., 2002), it is suggested that the production of biosurfactants in strains that showed a high degree of emulsification be investigated.

Jennings and Tanner (2000) compared the amount of biosurfactant producing microorganisms isolated from contaminated and uncontaminated sites. The percentage of biosurfactant producers in non-contaminated oil environments is higher than in the contaminated ones. This confirms that environments that have never been exposed to contaminants also have biosurfactant producing microorganisms and most of them belong to the genera Bacillus and Pseudomonas.

Another application of surfactants is in the therapeutic area. According to Nitschke and Pastore (2002), the biosurfactant produced by R. erythopolis inhibited herpes simplex virus and parainfluenza virus. Emphasis should be put on the study of those molecules because they are becoming increasingly more promising as a replacement for 
highly environmentally aggressive chemical products that are currently being used in industry, in wastewater treatment and in rehabilitation of contaminated sites.

\section{DGGE analysis}

DGGE analysis showed a great variation in the structure of the bacterial communities present in the water held in tank bromeliads: no cluster was observed in different seasons over the year (wet and dry seasons), in the different locations studied (with and without anthropogenic activity) as well as under different light exposure (with more or less U.V. radiation). Moreover, the richness score and bands number showed a high variation in the replicates and conditions tested, which also shows there is a great difference among tank bromeliads, suggesting that each one is a singular habitat to a bacterial community. Similar result was observed by Farjalla et al. (2012) that evaluating the profile of the microbial community of Aechmea nudicaulis, Aechmea lingulata, Vriesea neoglutinosa, and Neoregelia cruenta demonstrated that bacteria had no habitat associations.

Although there is no statistical difference in the richness score in all conditions studied, great disparity was found between the samples from the Itacoatiara and Colibri regions. In the Colibri region samples the variation of the richness score and the bands number of the replicates is lower, which may have occurred due to anthropogenic activity. The Itacoatiara region receives a large number of human visitors, whereas the Colibri region is more preserved.

The amount of organic material decomposition, the presence of algae and sunlight are factors that seem to be important to determine the species present in the water held in tank bromeliads. The presence of a particular species of animal in phytotelma is the result of many processes, some quite obvious and others less so. A species will be present in a determined tank bromeliad because there are no predators, the plant is located at a given height, exposed to a certain amount of sunlight, to certain prey, etc. The same occurs with microorganisms based on nutrient availability, the physicochemical properties of the water and the presence of specific or casual vectors.

Collectively, those results suggest that tank bromeliads of the $N$. cruenta species provide distinct habitats for the bacterial community. For that reason and for the enzimatic results revealed in this work, those microorganism reservoirs can be seen as excellent sources for the search for new bioactive composites of bacterial origin.

\section{References}

Andreote FD, Azevedo JL, Araujo WL (2009) Assessing the diversity of bacterial communities associated with plants. Braz J Microbiol 40:417-132.

APHA/AWWA/WEF. Standard Methods for the Examination of Water and Wastewater, 20. ed. Washington: APHA, 1998.

Araújo FV, Medeiros RJ, Mendonça-Hagler LC, Hagler AN (1998) A Preliminary Note on Yeast Communities of Bro-
meliad-Tank Waters of Rio de Janeiro, Brazil. Rev Microbiol 29:118-121.

Armbruster P, Hutchinson RA, Cotgreave P (2002) Factors influencing community structure in South American tank bromeliad fauna. Oikos 96:225-234.

Bairagi A, Ghosh KS, Sem SK, Ray AK (2002) Enzyme producing bacterial flora isolated from fish digestive tracts. Aquacult Int 10:109-12

Bull AT, Stach JEM (2004) An overview of biodiversity estigmating the scale. In: Bull, AT (eds). Microbial Diversity and Bioprospecting. ASM Press, Washington, DC.

Cherif A, Quazri H, Daffonchio D, Cherif H, BenSiama K, Hassen A, Japua S, Boudabous A (2001) Thurin 7: A novel bacteriocin produced by Bacillus thuringenesis BMG 1.7, a new strain isolated from soil. Lett Appl Microbiol 32:2432-2247.

De Azeredo LAI, Castilho LR, Leite SGF, Coelho RRR, Freire DMG (2003) Protease production by a Streptomyces sp. isolated from a Brazilian cerrado soil: culture medium optimization employing statistical experimental design. Appl Biochem Biotech 105-108.

Donia M, Humann MT (2003) Marine natural products and their potential applications as anti infective agents. Lancet Infect Dis 3:338-348.

Dutra JrWM, Neto JB, Moreira JCS, Biassus IO, Gier M (2000) Substituição parcial do milho por resíduos da pré-limpeza do arroz com adição de enzimas em rações para frangos de corte. II - Características de carcaça. Revista Fac Zootec Vet Agro 7:109-113.

Farjalla VF, Srivastava DS, Marino NA, Azevedo FD, Dib V, Lopes PM, Rosado AS, Bozelli RL, Esteves FA (2012) Ecological determinism increases with organism size. Ecol 93:1752-1759.

Giambiagi-Marval M, Mafra MA, Penido EGC, Bastos MCF (1990) Distinct groups of plasmids correlated with bacteriocin production in Staphyococcus aureus. J Gen Microbiol 136:1591-1599.

Goffredi SK, Kantor AH, Woodside WT (2011) Aquatic microbial habitats within a neotropical rainforest: bromeliads and $\mathrm{pH}$-associated trends in bacterial diversity and composition. Microb Ecol 61:529-42.

Hagler AN, Rosa CA, Morais PB, Mendonça-Hagler LC, Franco GM, Araujo FV, Soares CA (1993) Yeasts and coliform bacteria of water accumulated in bromeliads of mangrove and sand dune ecosystems of southeast Brazil. Can J Microbiol 39:973-977.

Heuer H, Smalla K (1997) Evaluation of community level catabolic profiling using BIOLOG GN microplates to study microbial community changes in potato phyllosphere. J Microbiol Methods 30:49-61.

Hong K, Tokunaga S, Kajiuchi T (2002) Evaluation of remediation process with plant-derived biosurfactant for recovery of heavy metals from contaminated soils. Chemosphere 49:379-387.

Jennings EM, Tanner RS (2000) Biosurfactant - Producing Bacteria found in contaminated and uncontaminated soils. Proceedings of the Conference on Hazardous Waste Research p.299- 305 .

Lealem F, Gashe BA (1994) Amylase production by a grampositive bacterium isolated from fermenting tef (Eraglostis tef.). J Appl Bacteriol 77:348-352. 
Lima DU, Loh W, Buckeridge MS (2004) Xyloglucan-cellulose interaction depends on the side chains and molecular weight of xyloglucan. Plant Physiol. Bioch 42:389-394.

Lopes MA, Nass LL, Melo IS (2005) Biotecnologia aplicada a prospecção e uso de serviços e funções da biodiversidade. Biotecnolog Ciênc Desenvolv 34:29-35.

Lopez LCS, Madeira JA, Torres KR, Rios RI (1993) Composição e dinâmica hídrica de phytotelmata de Aechmea nudicaulis e Neoregelia cruenta (Bromeliaceae Bromeloideae) de Restinga de Maricá/RJ. In: III Simpósio de Ecossistemas da Costa Brasileira, Aciesp.

Lopez LCS, Rios RI (2001) Phytotelmata faunal communities in sun-exposed vs. shaded terrestrial bromeliads from southeastern Brazil. Selbyana 22:219-224.

Maggurran AE (1988) Ecological Diversity and its Measurement. Princeton University Press, Princeton, NJ.

Mestre LAM, Aranha JMR, Esper MLP (2001) Macroinvertebrate fauna associated to the bromeliad Vriesea inflate of the Atlantic Forest (Paraná State, Southern Brazil). Braz Arch Biol Technol 44:89-94.

Mingardon F, Chanal A, Tardif C, Fierobe H (2011) The Issue of Secretion in Heterologous Expression of Clostridium cellulolyticum Cellulase-Encoding Genes in Clostridium acetobutylicum ATCC 824. Appl Environ Microbiol 77:2831-2838.

Molina SMG, Pelissari SA, Vitorello CBM (2001) Screnning and genetic improvement pectinolytic fungi for dugumming of textile fibers. Microbiol 32:320-326.
Motta AS, Cladera-Olivera F, Brandelli A (2004) Screening for antimicrobial activity among bacteria isolated from the Amazon Basin. Braz J Microbiol 35:307-310.

Nettesheim FC, Menezes LFT, Carvalho DC, Conde MMS, Araujo DSD (2010) Influence of environmental variation on Atlantic Forest tree-shrub-layer phytogeography in southeast Brazil. Acta Bot Bras 24:369-377.

Nitschke M, Pastore GM (2002) Biossurfactantes: propriedades e aplicações. Quím. Nova 25:772-776.

Oliveira VM, Sette LD, Fantinatti-Garboggini F (2006) Preservação e prospecção de recursos microbianos. MultiCiência: construindo a história dos produtos naturais, p.19.

Rivera SC, Hazen TC, Toranzos ZA (1988) Isolation of fecal coliforms from pristine sites in a tropical rain forest. Appl Environ Microbiol 54:513-517.

Ter Braak CJF, milauer P (2002) CANOCO Reference Manual and CanoDraw for Windows User's Guide: Software for Canonical Community Ordination (version 4.5). Ithaca, NY, USA (www.canoco.com): Microcomputer Power.

Weinbauer MG, Wenderoth DF (2002) Microbial Diversity and Ecosystem Functions - the Unmined Riches. Electron J Biotechn 5:19-20.

Williams ST, Goodfellow M, Alderson G, Wellington EMH, Sneath PHA, Sackin MJ (1983) Numerical Classification of Streptomyces and Related Genera. J Gen Microbiol 129:1743-1813.

Willumsen PA, Karlson U (1997) Screening of bacteria, isolated from contaminated soils, for production of biosurfactants and bioemulsifiers. Biodegradation 7:415-423.

All the content of the journal, except where otherwise noted, is licensed under a Creative Commons License CC BY-NC. 